\title{
Instant Mobile Messaging (WhatsApp) and Teaching Translation: Views Elicited from Saudi Translation Teachers and Students
}

\author{
Mubarak Alkhatnai ${ }^{1}$ \\ ${ }^{1}$ College of Languages and Translation, King Saud University, Riyadh, Saudi Arabia \\ Correspondence: Mubarak Alkhatnai, College of Languages and Translation, King Saud University, Riyadh, \\ 11635, Saudi Arabia. E-mail: malkhatnai@ksu.edu.sa
}

Received: May 13, $2019 \quad$ Accepted: June 17, $2019 \quad$ Online Published: August 26, 2019
doi:10.5539/ijel.v9n5p98
URL: https://doi.org/10.5539/ijel.v9n5p98

\begin{abstract}
This study investigated the views of Saudi translation teachers and students toward using instant messaging services (such as WhatsApp) in their translation learning and teaching. Using a qualitative research method (content analysis), three teachers' and 15 students' utterances were analyzed and the pros and cons of using this type of technology described. While some participants raised technological and instructional pitfalls many also reported educational and social gains. The teachers and the students had different reasons for establishing chat groups and for the possible uses of this technology; however, all agreed it was effective for their teaching and learning. Suggestions for the integration of this technology into Saudi and international translation classes are also given.
\end{abstract}

Keywords: chat, computer mediated communication (CMC), instant messaging, WhatsApp, translation teaching and learning

\section{Introduction}

An important aspect of teaching language translation is to develop a communicative environment so that learners can meaningfully use the target language. Computer-mediated communication (CMC), or chatting, allows language learners to use the target language as part of their interactions with classmates, other learners, and native English speakers in different parts of the world. Chat has been defined as "a two-way form of CMC, a dialog in real-time as we keyboard or speak our words, an online conversation between two or more people" (Almeida d'Eca, 2002). Through this type of written exchange, students can negotiate meaning and form using the target language in a social context that provides them with real-life, real-time interactions.

This paper starts by reviewing chat room history and the pros and cons of using chat rooms for second language learning, especially for English. This paper also examines some of the sociocultural aspects of chatting and highlights the primary concerns of teachers and students. Although the scope of this study is focused mainly on WhatsApp as a communication tool, the discussion is equally valid for similar communication tools on computers and hand-held devices.

\section{Literature Review}

\subsection{History of Online Chatting}

Chatting can be traced back to Internet Relay Chat (IRC), which developed from earlier protocols such as talk and MUDs (Multi-User Dungeons). MUD emerged in the late 1970s and was popular during the late 80s and early 90s. Roy Trubshaw designed the first MUD in 1979 using a computer language known as MACRO-10. Trubshaw's early prototype needed 50K of RAM to run, a size that was then considered so immense that it took nearly all of limited system resources in the computers at that time. Talk was usually installed on UNIX machines and allowed only two people on the same local network or remotely to communicate in real-time; each user could see the other user typing, constructing, and modifying sentences in a split window. MUDs, which unlike talk could potentially host hundreds of users at the same time, were text-based exploration games in which users created characters and then chatted, or solved puzzles in specially created rooms. IRC, therefore, was a merging of MUDs and talk; instead of characters, IRC used "nicks", short for nicknames, and instead of rooms, users could create chat channels. IRC was developed in summer 1988 when Jarkko "WiZ" Oikarinen wrote the first IRC client using a server at the University of Oulu, Finland. By the middle of 1989, there were 40 
servers worldwide, and by 1991, there were 69 American based IRC servers and only 66 non-American servers. By October 1995 IRC, servers were visited over 15,000 times a month, and by April 1997, this had risen to 30,000 visits (Hamman, n.d.).

IRC's first became popular during the Iraqi invasion of Kuwait in 1991 when it was used to relay information from inside Kuwait to the outside world because all other forms of communication had been cut off. Live reports were available and more than 300 concurrent users were logged onto IRC at the same time, a new record at that time. Messages on IRC were echoed to individuals logged onto an IRC server to any specific channel(s) they joined. A channel was similar to a text-based conference call, where people with similar interests could join and communicate; these channels were the precursors to current chatrooms.

\subsection{Modern Chat Interfaces}

Unlike older protocols such as talk, IRC did not display the text while the users composed it; that is, other parties could not see user comments until they pressed (enter). User messages were displayed as ongoing transcripts with all contributions being timestamped to mark the exact time a statement was made. Chatting in USENET-style discussion groups and sharing files was the reason many people in the 80 s and early $90 \mathrm{~s}$ started using the Internet. These early interactive protocols made the Internet seem socially attractive and not just a meeting place for computer specialists.

With the emergence of hand-held devices in the 2000s, chat was elevated with many different platforms for chatting and exchanging files. WhatsApp is one of the more recent platforms.

WhatsApp was launched in 2010 and has attracted more than 350 million users worldwide. Cohavi (2013) claimed that WhatsApp was the most downloaded app in more than 127 countries at that time, and Tzuk (2013) reported that up to 2013, more than 31 billion messages had been sent. Audio and video files, images, Pdfs, messages, and links can be sent via this app to other people in the groups. Due to its simplicity and because it is free to download on any operating platform, WhatsApp has gained in popularity.

Though WhatsApp is a relatively new technology, many researches have been conducted on using this technology in a language learning teaching context, though just a few researches have been carried out on its use in Saudi Arabia. Alshammari et al. (2017) argue that mobile applications such as WhatsApp ought to be to maximum advantage to inspire independent and collaborative learning, where language teachers work as catalysts to foster learning communities.

Masithoh and Fauziati (2017) in their research on the utilisation of communication strategies, like WhatsApp and SMS as crucial tools in the English language learning, discovered that learners employed these communication tools to overcome the difficulties they experienced in using English. "It would be of great benefit, therefore, for language instructors to create such awareness of the possible variations of communication strategies. So, the students can compensate with the language deficiencies. They can overcome the problems that inhibit their communication" (Masithoh \& Fauziati, 2017, p. 88).

Salehi (2017) in his research on learning English collocations has found that "WhatsApp as one of the messaging applications has become popular among learners in various classroom settings that have allowed them to communicate with others in their contact list through text" (p. 37). He considers WhatsApp as a multipurpose, invaluable tool for teaching vocabularies to L2 learners. After performing diverse investigations and evaluations, he came to the conclusion that as regards the acquisition of English collocations, those who received instructions through WhatsApp outperformed the other group that received traditional learning.

\subsection{Before Using Chat Rooms in the Translation Classroom}

Before implementing chat as part of the curriculum, teachers need to consider whether chat-oriented tasks can provide students with a better opportunity to learn the target language. While developing technological skills through language learning could also be useful, a focus on technology should not distract instructors from the main goal of teaching language. Cummins (2000) stated that "information technology has considerable potential to promote language learning in a transformative way when it is aligned with a pedagogy oriented toward promoting collaborative relations of power in the classroom and beyond" (p. 539). Therefore, if done in a pedagogically sound fashion, EFL programs could be enhanced through technological integration.

Teachers also need to ensure that the activities promote interaction. As new technological tools are integrated into conventional classrooms, tasks need to be reevaluated and reorganized by considering the ways that the use of computer technology can change the learning, student to student, and student to teacher dynamics (Krug, 2001). 
However, because of the flexibility of technology, different types of tasks can be used with IRC. For example, problem-solving tasks requires a higher degree of turn taking between negotiations, and debating tasks have longer turns and more complicated and longer discourse structures (Duff, 1999). Lee (2002) claimed that "the key is to structure tasks that involve learners' active participation in sharing, exchanging, and debating information relevant to life experiences through self-expression and self-discovery" (p. 18), and argued that task-based instruction fostered this goal because of the theme-based contexts and the open-ended questioning that allowed learners to meaningfully use the language. Lee (2002) also claimed that while exchanging information, students could pay attention to both structure and meaning. Lee pointed out, however, that design principles varied depending on the results desired by the teacher. Kelm (1992) claimed that interactions using $\mathrm{CMC}$ were similar to real conversations as the learner output was simple for, they used short rather than complex sentences. Beauvois (1998) found that students enrolled in an intermediate French course that used an electronic synchronous communication software program for class discussion performed better on oral exams than those who had spent the same amount of time in oral classroom discussions.

\subsection{Interaction}

Krashen (1981) believed that comprehensible input was both a necessary and a sufficient condition for language acquisition; however, Ellis (1985) claimed that both input and interaction influenced second language acquisition, as interaction elicited greater input than input alone. Through chatting interactions, learners can control the content and participate in a wider range of speech acts, directives, and utterances while practicing the language.

\subsection{Online Interactions}

Chat rooms can offer greater opportunities for interaction. Bravo et al. (2017) stress on the importance of website resources like chat-rooms and blogs and believe that these means of interaction should be furthered and spread as useful tools for second or foreign language learning. As for translation into a second language, these internet resources equip Saudi learners and teachers with enough communicative skills to write and try out translation into a new language, with proper sentence structures, phrases, and words. It also develops second language learners and teachers' levels of thinking and reflection, which can be more helpful in their translation tasks (Bravo et al., 2017). This interaction, even though it is written and not face-to-face, can be more authentic than the more traditional forms of classroom communication. Davies, Shield, and Weininger (1998) claimed that:

There is a real possibility to interact "naturally" with native speakers - comMUnication is real, despite the virtual interlocutors, whereas the target language interaction in the classroom is quite often unreal, despite the real interlocutors. Perhaps most importantly, though, is that the target language switches focus within any MOOing activity: language is no longer a goal but an instrument to pursue other (real) goals; integrating into the MOO's Community is socializing in the target language, one of the highest-ranking activities in foreign language learning (pp. 17-18).

The letters in the upper case show how second language English learners produce some sounds and stresses when speaking English, which may hinder proper translation. Chat can be used among students in pairs or groups in the same classroom or with individuals in other parts of the world. Freiermuth (1998) argued that it was better to have students chat with other students in the same class for a number of reasons; native speakers may lack any interest in chatting with non-native speakers of low proficiency, native speakers may use difficult language or fail to focus on a specific topic, and non-native speakers may be confronted with harsh language and insults from less compassionate users. Using chat rooms or other sites that are specifically intended for non-native speakers could solve some of these problems; however, limiting students to non-native chat sites may result in a dumbed-down, unrealistic version of the language and confine students to a type of segregated ESL group. Krashen (1981) believed that the attainment of a higher proficiency required exposure to language of a slightly higher complexity; therefore, creating student groups of identical levels could demotivate students compared to mixed-level groups that may include native speakers. Teachers also need to give students certain tasks to focus the chatting such as finding information and reporting back.

\subsection{Organizing a Class Chat Room}

To organize a chat room, it is necessary to have access to an IRC (Internet Relay Chat) server or service and configure an IRC client. We do not need IRC in the case of Whatsapp. The IRC procedure is freely available, it is advanced and stable, and has been put into operation in various projects. This implies that it can be used liberally, for both open-source and commercial projects IRC servers can be local, such as a school network, or a third-party server could be used. Several IRC networks and servers can be accessed without charge and there are also ways to secure channels so that non-class members cannot enter. After teachers are familiar with the basic IRC commands (such as joining and parting a channel, as well as private messaging), they can create a specific 
channel for students to use. Students should be given a brief IRC tutorial to familiarize themselves with the commands and become comfortable with the interface. Chat room visits need to be regularly scheduled and topic discussions determined ahead of time, allowing students to plan ahead and put the topics into the proper context as student preparation and an understanding of the session objectives and the follow up activities is crucial for successful interactions. Omaggio-Hadley (1993) claimed that students comprehend and communicate with greater fluency in a target language when the issues and topics are contextualized. Chats also need to be student-centered, with the role of the teacher in the online discussions being more of a facilitator to keep the discussion on track, assist with technical difficulties, and act as a moderator, as they would in face-to-face oral discussions in the classroom.

Even though the rise of mobile phones and the use of apps such as WhatsApp have changed the way people chat, the above arrangements for chat-based classes are still largely applicable; therefore, teachers need to plan carefully before implementing any sort of technology.

\subsection{Language Socialization on IRC}

Language socialization researchers (Baquedano-Lopez, 2001; Heath, 1983; Valdez, 1996) agreed that language learning was a socialization process in which the students acquire a particular status in the social environment in which they are learning. Gee (1996) also claimed that literacy involved more that reading and writing, and was part of a set of practices (discourses) that enacted the cultural norms of a particular social group and the identity of the person in that group.

The online environment and IRC have fostered a rise in social and political interest groups, in which language is used to construct communal affiliations, sociocultural beliefs, establish identities, and define power relations (Lam, 2003). IRC users adhere to an elaborate chat etiquette, where the standards for greetings, introductions, leaving, seeking technical assistance, and general discourse are unofficially agreed upon and only vary depending on the online subcultures and communities. IRC can also assist students develop skills that are essential for life; for example, chatting can encourage independence, autonomy, listening, debate, and negotiation. Cueto et al. (2018) explored in their research work the usefulness of technology in the field language learning and translation and discovered that tools like chatting can go a long way in helping students learn a language which eventually helps them in translation. Zhou (2018) observes that "Mobile learning has recently emerged as a new type of learning model which allows learners to obtain learning materials anywhere and anytime using mobile technologies and the internet" (p. 26). He asserts that the mobile devices play a crucial role in supporting language learning that indirectly helps learners in their translation tasks. IT helps in learning vocabulary, collocations, and grammar points which it makes easily accessible. Through mobiles learners can be offered with some tailored modified vocabulary exercises centred on classroom activities. They are, then, required to carry them out on their mobile phones. This helps them acquiring new vocabularies which can assist them in speeding up their translation tasks. Grammatical points can be also be acquired by installing on mobile phones exclusively devised programs. These programs teach grammatical rules, and offer multiple-choice activities, fill-in-the-blanks exercises, and true-false exercises, giving the learners the freedom to write or choose their answers, and then they are able to correct their errors fast. Grammatical details and clarifications are also may presented to learners which helps them in understanding the grammatical points cogently, and in no time. This can also go a long way in helping learners to undertake their translation projects without errors and taking less time than doing the job in a traditional language learning atmosphere.

\subsection{The Use of Chat Tools by Saudi EFL Teachers and Learners}

Research on ICT (Information and Communication Technology) use by Saudi teachers and learners has found that it is being used for both educational and recreational purposes (Alkhatnai, 2013). A recent study (Alabdulkareem, 2015) explored the use and impact of social media on the teaching and learning of science in Saudi Arabia. Conducted within the same institute as the current study, it was found that WhatsApp was the most highly used social media site by both teachers $(100 \%)$ and students $(72.44 \%)$. It can, therefore, be comfortably deduced from this observation that WhatsApp emerges as a vital and viable tool of language teaching as well as learning.

\section{Methodology}

As this study was exploratory in nature, a qualitative research approach was seen to be the best approach for answering the research questions. Brown (2006) claimed that "Exploratory research tends to tackle new problems on which little or no previous research has been done" (p. 34); therefore, it is hoped that this research will open doors for future research in this area. Singh (2007) stated that "exploratory research is the initial research, which forms the basis of more conclusive research. It can even help in determining the research design, 
sampling methodology, and data collection method" (p. 64). A qualitative approach was preferred over a quantitative method in the hope of yielding more usable data. Quantitative research is generally more concerned with finding answers to specific questions while qualitative research can explore narratives to more fully examine a topic. Qualitative research also allows the interviewer and interviewees to deal with issues as they arise in the interviewing process, thereby yielding richer data.

Semi-structured interviews were conducted during the second semester of 2015 with three teachers and 15 English major students at the College of Languages and Translation at King Saud University, Riyadh, Saudi Arabia. Teachers were chosen that were already using WhatsApp as a teaching and learning resource. An invitation to join the study was then sent to all students (between 28 and 39 in each group) in each of the teacher's respective groups. However, a cut off was made at the first 15 to volunteer as this represented around 10 percent of the possible study population. Participants were told the purpose of the interviews, which were informal and conversational as recommended in previous research (Trochim, 2002). A content analysis method was used to discover the main themes from the interviews.

The interview data were not categorized into pre-determined categories; rather, the data were classified and explanatory notes added as the interviews proceeded. The final data included information on the motivation, the advantages, and the disadvantages of using the technology, the learning experiences gained, and the way the technology affected the student-student and student-teacher interactions. After the interviews ended, the data were coded and categorized based on the outcomes received from the students and teachers, and analysed and interpreted as the findings of the study, in the following sections, through the Tables.

\subsection{Description of Users and Exchanged Messages}

As Saudi Higher Education is segregated, with the different sexes studying in different sections, the teacher and student participants were all male in this study. The students were in their first year of college after the university Preparatory Year, with all having a moderate to advanced level of English as the department requires a moderate 5 IELTS score for admission. Irrespective of the Group language, the interviews were conducted in English and the students were given time to respond. Table 1 gives information about the participants, their roles in the groups and the groups' main language or languages.

Table 1. Demographics of the study participants

\begin{tabular}{lllll}
\hline Name & No of Whats App Groups & No of students per group & Role within the group & Group Language \\
\hline T1 & 4 & 25 & Moderator & English \\
T2 & 2 & 28 & Member & Arabic and English \\
T3 & 3 & 33 & Moderator & English \\
S1 & 1 & 28 & Member & English \\
S2 & 3 & 25 & Member & English \\
S3 & 2 & 25 & Moderator & English \\
S4 & 5 & 28 & Moderator & Arabic and English \\
S5 & 3 & 28 & Member & English \\
S6 & 2 & 28 & Member & English \\
S7 & 3 & 28 & Member & English \\
S8 & 1 & 28 & Member & Arabic and English \\
S9 & 2 & 25 & Member & English \\
S10 & 3 & 33 & Member & English \\
S1 & 4 & 33 & Member & English \\
S12 & 2 & 25 & Member & English \\
S13 & 3 & 28 & Member & Arabic and English \\
S14 & 3 & 25 & Member & English \\
S15 & 4 & 33 & Moderator & English \\
\hline
\end{tabular}

\section{Research Findings}

\section{Reasons, benefits and limitations of using chat}

All participants were asked about why the chat groups were established (Table 2), as well as the advantages and disadvantages of using WhatsApp in the class.

The main purposes for setting up the WhatsApp groups were communicating with each other, social interaction, and as a replacement for other learning platforms. Educational, instructional, social, and technological reasons 
were given as the benefits and drawbacks.

Table 2. Reasons, benefits and drawbacks for using WhatsApp

\begin{tabular}{|c|c|c|c|}
\hline Name & Group purposes arranged by importance & Advantages & Disadvantages \\
\hline $\mathrm{T} 1$ & $\begin{array}{l}\text { Communicating with students } \\
\text { Creating a rapport with students } \\
\text { Communicating with colleagues } \\
\text { Creating a learning environment } \\
\text { Language practice purposes }\end{array}$ & $\begin{array}{l}\text { Quick resources } \\
\text { Social atmosphere } \\
\text { Sharing pdfs and docs } \\
\text { Sharing learning unlimited resources } \\
\text { Anytime anywhere communication }\end{array}$ & $\begin{array}{l}\text { Limited group numbers } \\
\text { Replying to certain individuals } \\
\text { while in group }\end{array}$ \\
\hline $\mathrm{T} 2$ & $\begin{array}{l}\text { Send assignments } \\
\text { Notify students } \\
\text { Reach all students } \\
\text { Keep a record of messages } \\
\text { Instant feedback } \\
\text { Replacement for the learning management } \\
\text { system (LMS) }\end{array}$ & $\begin{array}{l}\text { Notification upon receiving } \\
\text { Being concise and economical } \\
\text { Practicing language freely with classmates } \\
\text { Getting over language anxiety Saves time }\end{array}$ & Consumes mobile storage \\
\hline $\mathrm{T} 3$ & $\begin{array}{l}\text { Practice English both written and sometimes } \\
\text { spoken through voice messages } \\
\text { Practicing formal and informal language } \\
\text { Exchanging resources } \\
\text { Getting in touch with native speakers }\end{array}$ & $\begin{array}{l}\text { Better than other communication tools } \\
\text { (email) } \\
\text { Very easy technology } \\
\text { No prior technology knowledge needed } \\
\text { Multilingual }\end{array}$ & $\begin{array}{l}\text { Needs too much space on the } \\
\text { phone (media and files) }\end{array}$ \\
\hline S1 & $\begin{array}{l}\text { Getting in touch with friends } \\
\text { Work on projects and assignments together } \\
\text { Easier compared to other means }\end{array}$ & $\begin{array}{l}\text { Sharing knowledge } \\
\text { Team work } \\
\text { Created an atmosphere with my classmates } \\
\text { Constant updates }\end{array}$ & Consumes time \\
\hline $\mathrm{S} 2$ & Getting in touch with classmates & Free and simple to use & Too hard to follow discussions \\
\hline S3 & $\begin{array}{l}\text { Quick response } \\
\text { Quick feedback }\end{array}$ & & $\begin{array}{l}\text { The information is not } \\
\text { categorized/classified }\end{array}$ \\
\hline S4 & $\begin{array}{l}\text { Contact with the teacher } \\
\text { Help translating difficult words }\end{array}$ & Very famous worldwide & $\begin{array}{l}\text { No ethics on what to send and what } \\
\text { not to send }\end{array}$ \\
\hline S5 & Sharing stuff with my classmates & Share any type of media or links & Irrelevant things for all students \\
\hline $\begin{array}{l}\text { S6 } \\
\text { S7 }\end{array}$ & $\begin{array}{l}\text { Share media and files quickly } \\
\text { Easy access } \\
\text { Communicating with teacher and students }\end{array}$ & Quick and instant & $\begin{array}{l}\text { Too personal sometimes } \\
\text { Teacher authority is gone } \\
\text { No class interaction } \\
\text { Students rely on it } \\
\text { Changed the class dynamics }\end{array}$ \\
\hline S8 & $\begin{array}{l}\text { A learning environment } \\
\text { A communication tool } \\
\text { Close relationship with my teacher }\end{array}$ & Everybody uses it & \\
\hline S9 & Getting access to course materials & Chats are private and secure & $\begin{array}{l}\text { People changing their numbers } \\
\text { Shortened form of language }\end{array}$ \\
\hline $\mathrm{S} 10$ & $\begin{array}{l}\text { Practice my writing skills } \\
\text { Exchange words meanings and translations }\end{array}$ & $\begin{array}{l}\text { Belonging to a group } \\
\text { Getting help at anytime }\end{array}$ & Flood of messages \\
\hline S11 & The teacher asked me to join & I can help friends when in need & $\begin{array}{l}\text { Mostly informal } \\
\text { Street language }\end{array}$ \\
\hline $\mathrm{S} 12$ & Almost all courses use the same method & $\begin{array}{l}\text { Confidence in asking and inquiring and } \\
\text { checking the accuracy of translation }\end{array}$ & $\begin{array}{l}\text { Too much personal info } \\
\text { Unavailability of teachers } \\
\text { Irrelevant topics or info } \\
\text { Class authority is misplaced }\end{array}$ \\
\hline S13 & $\begin{array}{l}\text { I like it better than Blackboard } \\
\text { I do not like to speak in front of others, they } \\
\text { can read my ideas later }\end{array}$ & $\begin{array}{l}\text { Contact with other colleagues even if not } \\
\text { classmates } \\
\text { Can invite outside to join in discussion } \\
\text { without being physically there }\end{array}$ & Some students isolated themselves \\
\hline S14 & $\begin{array}{l}\text { Building both written and spoken } \\
\text { communication skills } \\
\text { Exchanging authentic materials }\end{array}$ & $\begin{array}{l}\text { Instant feedback from friends or teacher } \\
\text { Teacher's effort is preserved. Other } \\
\text { students help instead }\end{array}$ & $\begin{array}{l}\text { Go off topic } \\
\text { Group administration } \\
\text { Conflicts } \\
\text { No etiquette }\end{array}$ \\
\hline S15 & $\begin{array}{l}\text { Contacting friends } \\
\text { Contacting native speakers when in need }\end{array}$ & $\begin{array}{l}\text { Teacher is available anytime } \\
\text { Beyond class interaction }\end{array}$ & No learning effort \\
\hline
\end{tabular}

\subsection{Reasons for Establishing WhatsApp Groups}

All participants claimed that the chat groups were established primarily for educational reasons; for example, many participants claimed that the chat groups "created a learning environment" and they were able to 
"exchange learning resources". T1 said:

"I think WhatsApp is a very effective learning tool. Students exchange learning resources and materials anywhere and anytime. They benefit from each other and discuss projects, concept, meanings of certain terms, and the issues they face in their classes and exchange with people even from outside of their classes."

Other educational reasons for using WhatsApp included creating a relaxed learning environment. T2 said; "I learned many things about my students ... I know how they learn better and what sort of learning materials they prefer especially when they are doing a translation task." S5 also saw a similar educational benefit:

I believe it [WhatsApp] helped me understand my teacher better. In class we usually have little time to ask or even greet the teacher feedback on our translations. I thought at times that he was ignoring some questions but now I get to ask as many questions as I like and the teacher will endeavor to answer or my classmates will help me if they know.

The third reason for establishing WhatsApp was as a replacement for other technologies and learning platforms. Many participants highlighted the ease of using WhatsApp compared to the learning management system (LMS) in the university. One teacher (T1) said:

The university uses Blackboard as the main learning management system (LMS) and students and teachers are encouraged to use it in their courses. However, this LMS requires a lot of effort and requires time and $\log$ ins. WhatsApp on the other hand requires no effort and is very user-friendly. It, without doubt, replaces many features of the LMS in a better way.

\subsection{Benefits and Limitations}

A well-planned chat session can foster higher levels of collaboration than more traditional face-to-face classroom discussions. Shyer people may be more likely to participate in a chat room and the ability to edit while composing can lower the anxiety of some less-proficient students. The opportunity to chat with different people thousands of miles away is also a unique characteristic of chat group discussions (Kelm, 1992). Students are also more likely to ask open-ended questions, which helps the discussion gain momentum and gain a life of its own (Freiermuth, 2001). However, the quality of the students' interactions is still dependent upon sound planning by teachers, as students must be challenged with quality tasks to become engaged in the collaborative tasks.

An additional benefit of WhatsApp was that it provided teachers with a way to easily assess student translation ability and language use, as student dialogs could be made into text documents for textual, sentence, and discourse analysis. It can be reasonably deduced from the interviews conducted for this research that written debates generally elicited more complex language than oral debates, and learners tended to produce longer, more coordinated and subordinated utterances. As learners in electronic environments are not pressured by time constraints, they are able to plan and edit their messages more carefully, thereby creating a language that is richer and more complex. By analysing these utterances, the teachers said that they could more accurately identify the student difficulties and provide more focused solutions.

A third benefit of chatting was that it helped break down the student/teacher dichotomies. In an electronic discussion a lone lecturer standing in front of the class does not intimidate students, with the student/teacher relationship in the chat room being somewhat equal; therefore, students feel that they can participate without interruptions, time constraints, or anxiety.

Lastly, as operating an IRC client such as WhatsApp is not difficult, even the least technically intelligent students found it easy to use; therefore, chatting becomes an entertaining tool that students can use to improve their language skills, rather than a complex program that must be battled with to master.

While there are a number of advantages to chatting, several limitations were also mentioned, many of which could be avoided through thorough planning and the identification of clear and valid objectives.

The first potential problem with chatting is its heavy use of abbreviated, oversimplified language, as this can be confusing to second language learners, and also misleading if they are not aware of the formal use. While the simplified language involved in instant messaging can save time, students need to be aware of the differences between online chatting discourse and formal spoken and written English (Lee, 2002).

Second, teachers need to consider the potential technical problems before using chatting as part of their language classes. Malfunctioning phones or computers, network issues, and unreliable Internet connections are some potentially problematic situations that may arise. The use of any technology in the classroom requires a certain amount of preparation and testing before final implementation. 
Lastly, the native speakers in public WhatsApp groups may discuss topics that are inappropriate or offensive to some learners, or specific to the English-speaking world, especially in multi-cultural classes. For this reason, teachers should assess their students' cultural proficiency and language backgrounds before implementing chatting apps in the classroom and need to choose online environments that foster linguistic growth.

\section{Conclusion}

While Chatting should not be seen as a replacement for in-class discussions, these resources can be used to supplement learning and increase communicative practice. Online collaborative language learning tasks can be very successful, and teachers can easily monitor students while they are chatting to assess the output, which allows the students to take more control over their own learning. However, complex tasks need to be introduced to guide the chat and enough time given for task completion. Chatting apps such as WhatsApp are strong, effective communication tools that can enable a fascinating, authentic, and enriching learning experience when properly integrated into EFL curricula.

\section{Acknowledgments}

The author would like to thank the Deanship of Scientific Research, King Saud University for supporting this research.

\section{References}

Alabdulkareem, S. (2015). Exploring the Use and the Impacts of Social Media on Teaching and Learning Science in Saudi. Procedia - Social and Behavioral Sciences, 182, 213-224. https://doi.org/10.1016/j.sbspro.2015.04.758

Alkhatnai, M. (2013). Strategic use of ICT in the Saudi system of higher education: King Saud University. Ph.D Thesis, The University of Edinburgh. Retrieved from http://hdl.handle.net/1842/8869

Almeida d'Eça, T. (2002). To chat or not to chat in the EFL classroom. Paper presented at the Language-Communication-Culture International Conference, University of Evora, Portugal, November 29. Retrieved from http://www.malhatlantica.pt/teresadeca/papers/evora2002/chat-and-efl.htm

Alshammari, R., Parkes, M., \& Adlington, R. (2017). Using WhatsApp in EFL Instruction with Saudi Arabian University Students. Arab World English Journal, 8(4), 68-84. https://doi.org/10.24093/awej/vol8no4.5

Baquedano-Lopez, P. (2001). Creating social identities through doctrina narratives. In A. Duranti (Ed.), Linguistic anthropology: A reader (pp. 343-358). Oxford, England: Blackwell.

Beauvois, M. H. (1998). Write to speak: the effects of electronic communication on the oral achievement of fourth-semester French students. In J. A. Muyskens (Ed.), News Ways of learning and teaching: Focus on technology and foreign language education [AAUSC Issues in Language Program Direction] (pp. 93-116). Boston: Heinle and Heinle.

Bravo, J. C., Intriago, E. A., Holguin, J. V., Garzon, G. M., \& Arcia, L. O. (2017). Motivation and Autonomy in Learning English as Foreign Language: A Case Study of Ecuadorian College Students. English Language Teaching, 10(2), 100-113. https://doi.org/10.5539/elt.v10n2p100

Brown, R. B. (2006). Doing Your Dissertation in Business and Management: The Reality of Research and Writing. Sage Publications. https://doi.org/10.4135/9781849209069

Cohavi, A. (2013). How did Whatsapp became the strongest social network? Calcalist. Retrieved from http://www.calcalist.co.il/local/articles/0,7340,L-3593840,00.html

Cueto, M. d. C. H., et al. (2017). The Use of Technologies in Second Language Learning: The Case of a $\begin{array}{lllll}\text { Mexican University. European Scientific Journal, } & 13(25), & \end{array}$ https://doi.org/10.19044/esj.2017.v13n25p264

Cummins, J. (2000). Academic language learning, transformative pedagogy, and information technology: Towards a critical balance. TESOL Quarterly, 34(3), 537-548. https://doi.org/10.2307/3587742

Davies, L. B., Shield, L., \& Weininger, M. J. (1998). Godzilla can MOO, can you? MOOs for construction, collaboration and community and research. The Language Teacher, 22(2), 16-21.

Duff, P. (1999). Tasks and interlanguage performance: An SLA research perspective. In G. Crooks \& S. M. Gass (Eds.), Tasks and language learning: integrating theory and practice (pp. 57-95). Bristol, PA: Multilingual Matters Ltd.

Ellis, R. (1985). Understanding second language acquisition. Oxford, UK: Oxford University Press. 
Freiermuth, M. (1998). Using a chat program to promote group equity. CAELL Journal, 8(2), 16-24.

Freiermuth, M. (2001). Native speakers or non-native speakers: Who has the floor? Online and face-to-face interaction in culturally mixed small groups. Computer Assisted Language Learning, 14(2), 169-199. https://doi.org/10.1076/call.14.2.169.5780

Gee, J. P. (1996). Social linguistics and literacies: Ideology in discourses. London: Falmer Press.

Hamman, R. (2005). History of the Internet. Retrieved January 23, 2005 from http://www.socio.demon.co.uk/history.html

Heath, S. B. (1983). Ways with words. Cambridge, England: Cambridge University Press. https://doi.org/10.1017/CBO9780511841057

Kelm, O. (1992). The use of synchronous computer networks in second language instruction: A preliminary report. Foreign Language Annals, 25, 441-445. https://doi.org/10.1111/j.1944-9720.1992.tb01127.x

Krashen, S. (1981). Second Language Acquisition and Second Language Learning. Oxford: Pergamon.

Krug, D. (2001). Pedagogy, multimedia, and distance education, presentation at National Art Education Association National Convention. New York City.

Lam, W. S. E. (2003). Second language literacy and identity formation on the internet: The case of Chinese immigrant youth in the U.S. Unpublished doctoral dissertation, the University of California, Berkley.

Lee, J. (2002). Nu Shortcuts in School $R 2$ Much 4 Teachers. Retrieved June 19, 2003, from http://www.learningexperts.com/McQuillan/NYTimes\%20092002\%20RU\%20Ready.pdf

Lee, L. (2002). Enhancing learners' communication skills through synchronous electronic interaction and task-based instruction. Foreign Language Annals, 35(1), 16-23. https://doi.org/10.1111/j.1944-9720.2002.tb01829.x

Masithoh, H., \& Fauziati, E. (2017). Students' use of Communication in an Online Discussion via WhatsApp (pp. 84-89). In Proceedings International Conference on Indonesian Islam, Education and Science (ICIIES).

Omaggio-Hadley, A. (1993). Teaching language in Context (2nd ed.). Boston: Heinle and Heinle.

Salehi, H. (2017). A comparison of male and female learners' English collocation learning through using WhatsApp. International Journal of Research Studies in Educational Technology, 6(1), 25-42. https://doi.org/10.5861/ijrset.2016.1615

Singh, K. (2007). Quantitative Social Research Methods. SAGE Publications. https://doi.org/10.4135/9789351507741

Trochim, W. (2002). Types of Surveys. Research Methods Knowledge Base.

Tzuk, A. (2013). Whatsapp has 350 million active users a month [in Hebrew]. Calcalist. Retrieved October 23, 2013 from http://www.calcalist.co.il/internet/articles/0,7340,L-3615097,00.html

Valdez, G. (1996). Con respeto: Bridging the distances between culturally diverse families and schools. New York: Teachers College Press.

Zhou, Z. H. (2018). Second Language Learning in the Technology-mediated Environments. Asian Education Studies, 3(1), 18. https://doi.org/10.20849/aes.v3i1.307

\section{Copyrights}

Copyright for this article is retained by the author, with first publication rights granted to the journal.

This is an open-access article distributed under the terms and conditions of the Creative Commons Attribution license (http://creativecommons.org/licenses/by/4.0/). 